Jurnal Edukatif Volume 2 Nomor 1 April 2020 Halaman 28-37

EDUKATIF: JURNAL ILMU PENDIDIKAN

Research \& Learning in Education

https://edukatif.org/index.php/edukatif/index

\title{
Lembar Kegiatan Literasi Saintifik untuk Pembelajaran Jarak Jauh Topik Penyakit Coronavirus 2019 (COVID-19)
}

\author{
Adib Rifqi Setiawan ${ }^{1}$ \\ Pondok Pesantren Ath-Thullab, Madrasah Tasywiquth Thullab Salafiyyah (TBS) ${ }^{1}$, \\ e-mail : alobatnic@gmail.com ${ }^{1}$
}

\begin{abstract}
Abstrak
Riset ini bertujuan untuk merancang dan menerapkan beberapa lembar kegiatan literasi saintifik untuk pembelajaran jarak jauh topik penyakit Coronavirus 2019 (COVID-19) bagi siswa sekolah dasar. Pendekatan yang digunakan adalah metode kombinasi model eksploratoris berurutan yang melibatkan sampel 35 siswa sekolah dasar yang mengalami pembelajaran jarak jauh karena COVID19. Instrumen penelitian menggunakan rancangan lembar kegiatan literasi saintifik sesuai tahap inti pendekatan saintifik, yang telah ditinjau dan dinilai oleh para pakar. Pelaksanaan menunjukkan bahwa literasi saintifik siswa belum dilatih secara optimal, walau rancangan lembar kegiatan literasi saintifik ini dapat ditanggapi oleh siswa selama pembelajaran jarak jauh.
\end{abstract}

Kata Kunci: COVID-19, lembar kegiatan siswa, literasi saintifik, pembelajaran jarak jauh.

\begin{abstract}
This research goals to design and implement scientific literacy worksheets for distance learning in the topic of Coronavirus 2019 (COVID-19) to primary school students. The approach used is mixed method sequential exploratory model involving sample 35 primary students who take the distance learning due COVID-19. The research instrument used is design of scientific literacy worksheets based on the core stage of the scientific approach, which had been reviewed and judged by experts. The implementation shows that students' scientific literacy has not been trained optimally, although this design of scientific literacy worksheets can be responded by students during distance learning.
\end{abstract}

Keywords: COVID-19, distance learning, scientific literacy, student worksheets

@Edukatif: Jurnal Ilmu Pendidikan 2020

$\triangle$ Corresponding author :

Address : Jl. KH. Turaichan Adjhuri, Kota, Kudus, Indonesia

Email : alobatnic@gmail.com

Phone : + 62-856-4067-6017
ISSN 2656-8071 (Media Cetak)

ISSN 2656-8063 (Media Online) 


\section{PENDAHULUAN}

COVID-19 merupakan penyakit menular yang disebabkan oleh sindrom pernapasan akut coronavirus 2 (severe acute respiratory syndrome coronavirus 2 atau SARS-CoV-2). Virus ini merupakan keluarga besar Coronavirus yang dapat menyerang hewan. Ketika menyerang manusia, Coronavirus biasanya menyebabkan penyakit infeksi saluran pernafasan, seperti flu, MERS (Middle East Respiratory Syndrome), dan SARS (Severe Acute Respiratory Syndrome). COVID-19 sendiri merupakan coronavirus jenis baru yang ditemukan di Wuhan, Hubei, China pada tahun 2019 (Ilmiyah, 2020; Hui, et al., 2020). Karena itu, Coronavirus jenis baru ini diberi nama Coronavirus disease-2019 yang disingkat menjadi COVID-19. COVID-19 sejak ditemukan menyebar secara luas hingga mengakibatkan pandemi global yang berlangsung sampai saat ini. Gejala COVID19 umumnya berupa demam $38^{\circ} \mathrm{C}$, batuk kering, dan sesak nafas serta dampak paling buruk untuk manusia ialah kematian. Sampai 19 April 2020 pukul 10:38:37 WIB, dilaporkan terdapat 2.329.539 kasus terkonfirmasi dari 185 negara yang 160.717 orang diantaranya meninggal dunia serta 595.229 orang bisa disembuhkan (Johns Hopkins CSSE, 2020).

Pandemi global yang terjadi pula di Indonesia membuat banyak pihak berupaya ikut berperan serta dalam mengatasi. Para dokter umum dan spesialis angkat bicara bersama guna memberi penjelasan singkat kepada masyarakat maupun imbauan agar menjaga kebersihan diri dan lingkungan sekaligus tak banyak keluar rumah (Irene, et al., 2020). Grace Natalie Louisa sebagai tokoh politik ikut mengucapkan tanggapan secara lisan berupa usulan kepada government Indonesia agar memberikan Bantuan Langsung Tunai (BLT) kepada warga yang menggantungkan hidup pada pendapatan harian serta melakukan tes COVID-19 secara gratis (Louisa, 2020). Nahdlatul Ulama (NU) sebagai organisasi kemasyarakatan juga turut beraksi menanggapi dengan membentuk Satuan Tugas PBNU Cegah Covid-19. Salah satu hasil kerja yang dilakukan satgas ini ialah protokol di lembaga NU setiap tingkatan guna diberlakukan di setiap lembaga yang berafiliasi dengan NU.
Protokol ini disiapkan sebagai upaya agar warga NU dan masyarakat secara luas dapat memahami tentang COVID-19, bisa mencegahnya agar tidak terinfeksi, serta tidak panik dalam menanggapi (Ilmiyah, 2020).

Salah satu dampak pandemi Coronavirus 2019-20 ialah terhadap pendidikan di seluruh dunia, yang mengarah kepada penutupan luas sekolah, madrasah, universitas, dan pondok pesantren. Kami turut merasakan dampak tersebut berupa perubahan pelaksanaan pembelajaran di madrasah dan pondok pesantren. Rekan kami, Surotul Ilmiyah, yang sedang mengambil studi doktoral di Xiangya School of Public Health, Central South University (CSU), Changsha, Hunan, China, sampai saat ini belum bisa kembali ke universitas. UNESCO (United Nations Educational, Scientific and Cultural Organization) pada 4 Maret 2020 menyarankan penggunaan pembelajaran jarak jauh dan membuka platform pendidikan yang dapat digunakan sekolah dan guru untuk menjangkau peserta didik dari jarak jauh dan membatasi gangguan pendidikan (UNESCO, 2020). Sehubungan dengan perkembangan tersebut, Kementerian Pendidikan dan Kebudayaan (Kemendikbud) turut mengambil kebijakan sebagai panduan dalam menghadapi penyakit tersebut di tingkat satuan pendidikan (Kemendikbud, 2020). Secara global, hasil pantauan UNESCO menyebutkan bahwa sampai 13 April sebanyak 191 negara telah menerapkan penutupan nasional yang berdampak kepada 1.575.270.054 siswa (91.3\% dari populasi siswa dunia) (UNESCO, 2020).

Berdasarkan keadaan yang terjadi, kami turut menyusun lembar kegiatan siswa (LKS), guna memandu pembelajaran jarak jauh yang tidak banyak berbeda dengan kegiatan di sekolah. Sebagai pengajar, kami telah menerapkan pembelajaran literasi saintifik sejak awal tahun pembelajaran (Setiawan, 2020). Karena itu, diharapkan pembelajaran jarak jauh tetap mempertahanan proses pembelajaran literasi saintifik walau dengan cara dan tingkat berbeda. Guna menyelaraskan upaya tersebut dengan keadaan yang terjadi, kami menyusun LKS berdasarkan indikator literasi saintifik yang memuat topik COVID-19. 
Riset ini bertujuan untuk merancang dan menerapkan beberapa lembar kegiatan literasi saintifik untuk pembelajaran jarak jauh topik penyakit Coronavirus 2019 (COVID-19) bagi siswa sekolah dasar. Karena itu, pertanyaan riset ini ialah, "Bagaimana lembar kegiatan literasi saintifik untuk pembelajaran jarak jauh dalam topik penyakit Coronavirus 2019 (COVID-19)?"

\section{METODE PENELITIAN}

Riset ini membutuhkan data berupa kajian pustaka tentang karakteristik pembelajaran jarak jauh, indikator literasi saintifik, informasi terkait COVID-19, serta survei dan hasil penerapan rancangan LKS. Berdasarkan tujuan riset dan kebutuhan data, kami memilih memakai metode kombinasi (mixed method) (Sugiyono, 2018; Creswell, 2014; Fraenkel, Wallen, \& Hyun, 2012). Pendekatan ini dipilih karena kami ingin menyusun LKS berdasarkan kajian pustaka terkait karakteristik pembelajaran jarak jauh dan indikator literasi saintifik yang memuat topik COVID-19. Susunan tersebut kemudian dilihat keabsahan dan keandalannya berdasarkan survei kemudian diterapkan ke dalam pembelajaran, untuk diulas lebih lanjut dari sisi pelaksanaan. Karena urutan awal menggunakan metode kualitatif dan akhir memakai metode kuantitatif, model kombinasi yang digunakan berupa eksploratoris berurutan (sequential exploratory) (Sugiyono, 2018; Creswell, 2014; Fraenkel, Wallen, \& Hyun, 2012).

\section{HASIL DAN PEMBAHASAN}

Pembelajaran jarak jauh adalah pembelajaran ketika siswa dan pengajar tidak selalu hadir secara fisik secara bersamaan di sekolah. Pelaksanaan dapat sepenuhnya jarak jauh (hybrid) atau campuran jarak jauh dengan kelas (blended). Salah satu upaya pembelajaran jarak jauh paling awal muncul dalam iklan berjudul Caleb Philipps, Teacher of the new method of Short Hand yang diterbitkan melalui koran Boston Gazette pada tahun 1728 sebagai upaya pengajar mencari siswa yang ingin belajar dengan cara tersebut (Holmberg, 2005, hal. 13). Pembelajaran jarak jauh pertama seperti dialami pada saat ini dilakukan oleh Isaac Pitman pada tahun 1840-an, yang mengajarkan sistem steno dengan mengirimkan beberapa teks yang ditranskripsi menjadi steno pada kartu pos dan menerima transkripsi dari para siswa guna diberi umpan balik (Simonson, 2019, hal. 18). Unsur umpan balik adalah inovasi penting dari sistem Isaac Pitman. Perkembangan penggunaan internet telah menjadikan pembelajaran jarak jauh lebih mudah dan cepat, bahkan saat ini sekolah dan universitas virtual memberikan kurikulum daring penuh (Gold \& Maitland, 1999). Di Indonesia, salah satu universitas yang membuka fasilitas pembelajaran jarak jauh blended ialah program pasca sarjana Pendidikan IPA Universitas PGRI Semarang (UPGRIS) (Roshayanti, 2019).

Kelebihan pembelajaran jarak jauh antara lain: dapat memperluas akses pendidikan untuk masyarakat umum dan bisnis karena struktur penjadwalan yang fleksibel mengurangi efek dari banyak kendala waktu dan tempat, penyerahan beberapa kegiatan di luar lokasi mengurangi kendala kapasitas kelembagaan yang timbul dari kebutuhan bangunan infrastruktur, serta terdapat potensi untuk meningkatkan akses ke lebih banyak pakar dari beragam latar belakang geografis, sosial, budaya, ekonomi, dan pengalaman. Namun, pembelajaran jarak jauh juga memiliki kekurangan antara lain: hambatan untuk pembelajaran efektif seperti gangguan rumah tangga dan teknologi yang tidak dapat diandalkan, interaksi yang tidak memadai antara siswa dan pengajar, serta kebutuhan untuk pengalaman yang lebih banyak.

Pengamatan naturalistic yang kami lakukan terhadap pelaksanaan pembelajaran jarak jauh di Kabupaten Kudus pada tahap awal diterapkan menunjukkan bahwa pihak yang terlibat lebih banyak berupaya untuk beradaptasi dengan platform daripada kegiatan pembelajaran serta kesulitan dalam manajemen waktu dan disiplin diri. Karena itu, kami melihat bahwa siswa dan pengajar perlu menyepakati platform yang digunakan sekaligus waktu pelaksanaan. Kesepakatan ini harus diambil untuk mengurangi potensi gagal hanya karena tidak bisa menggunakan platform sekaligus tetap terdapat interaksi langsung selama pembelajaran (Setiawan, 2020). 
Sehubungan dengan keadaan tersebut, pembelajaran jarak jauh yang kami lakukan menggunakan platform WhatsApp. Layanan olah pesan ini dipilih karena biasa dipakai oleh pengajar (penulis) dan siswa (sampel) serta memungkinkan pengguna untuk mengirim pesan teks dan pesan suara, melakukan panggilan suara dan video, berbagi gambar, video, dokumen, lokasi pengguna, dan media lainnya. Waktu yang disepakati oleh pengajar dan siswa ialah pada pagi-siang hari seperti waktu sekolah pada umumnya. Kesepakatan waktu ini diambil agar proses pembelajaran tetap mempertahankan sisi interaksi secara langsung.

Pelaksanaan dilakukan dengan memberi bahan panduan kegiatan yang dibagikan setiap hari guna dilaksanakan kemudian hasilnya dilaporkan secara pribadi. Kekurangan cara ini ialah tidak langsung dapat menanggapi pertanyaan dan/atau laporan pelajar, tapi memiliki kelebihan berupa lebih bersifat personal ketimbang klasikal.

Bahan panduan kegiatan tersebut berupa lembar kegiatan siswa (LKS) yang memuat langkah kegiatan serta saran referensi yang dapat digunakan. Saran referensi utama berupa buku pelajaran yang dipakai ketika pembelajaran di sekolah. Sementara saran referensi tambahan berupa bacaan, gambar, audio, dan/atau video terkait topik yang dibahas.

LKS disusun berdasarkan tahap inti pendekatan saintifik dan indikator literasi saintifik. Tahap tersebut memuat beberapa langkah, yakni mengamati, menanya, mengolah informasi, mengomunikasikan hasil, serta menelaah kembali (Setiawan, 2017). Indikator literasi saintifik yang dipakai mengacu kepada Setiawan (2020), mencakup aspek menjelaskan masalah, menafsirkan data, dan mengomunikasikan informasi secara ilmiah serta merencanakan, melakukan, dan mengevaluasi penyelidikan ilmiah, yang dapat dilihat melalui tabel 1. Kaitan secara rinci antara langkah dan indikator dapat dilihat melalui tabel 2. Topik yang dipakai untuk setiap LKS terkait dengan COVID-19, berupa penjelasan tentang COVID-19, dampak kebijakan terhadap lingkungan sosial, tanggapan dari beberapa tokoh, serta cara masyarakat menanggapi. Secara keseluruhan, sebaran setiap topik dikaitkan dengan mata pelajaran terkait, yang disajikan melalui tabel 3.

Tabel 1. Indikator literasi saintifik setiap kompetensi

\begin{tabular}{|c|c|c|}
\hline Kompetensi & Indikator & Kode \\
\hline \multirow{2}{*}{$\begin{array}{l}\text { Menjelaskan masalah secara } \\
\text { ilmiah }\end{array}$} & Menerapkan pengetahuan ilmiah yang sesuai & A1 \\
\hline & Menyusun pertanyaan berdasarkan fokus masalah & A2 \\
\hline \multirow{2}{*}{$\begin{array}{l}\text { Merencanakan penyelidikan } \\
\text { ilmiah }\end{array}$} & Menentukan variabel penyelidikan & B1 \\
\hline & $\begin{array}{l}\text { Mengusulkan cara mengeksplorasi secara ilmiah terhadap } \\
\text { pertanyaan yang diberikan }\end{array}$ & B2 \\
\hline \multirow{2}{*}{$\begin{array}{l}\text { Melakukan penyelidikan } \\
\text { ilmiah }\end{array}$} & $\begin{array}{c}\text { Mengidentifikasi, menggunakan, dan menghasilkan model dan } \\
\text { representasi yang jelas }\end{array}$ & B3 \\
\hline & Mengidentifikasi asumsi, bukti, dan penalaran dalam bacaan & B4 \\
\hline \multirow{2}{*}{$\begin{array}{l}\text { Menafsirkan data secara } \\
\text { ilmiah }\end{array}$} & Menyajikan data menggunakan beragam representasi yang sesuai & A3 \\
\hline & Menafsirkan data secara ilmiah & A4 \\
\hline \multirow{2}{*}{$\begin{array}{l}\text { Mengevaluasi penyelidikan } \\
\text { ilmiah }\end{array}$} & $\begin{array}{l}\text { Mengevaluasi cara mengeksplorasi secara ilmiah terhadap } \\
\text { pertanyaan yang diberikan }\end{array}$ & B5 \\
\hline & Mengevaluasi argumen dan bukti ilmiah dari beragam tipe sumber & B6 \\
\hline \multirow{2}{*}{$\begin{array}{l}\text { Mengomunikasikan } \\
\text { informasi ilmiah }\end{array}$} & Menyimpulkan informasi berdasarkan analisis & A5 \\
\hline & Menjelaskan manfaat pengetahuan ilmiah bagi masyarakat & A6 \\
\hline
\end{tabular}


Tabel 2. Matriks indikator literasi saintifik dengan tahap inti pendekatan saintifik

\begin{tabular}{|c|c|c|c|}
\hline \multirow{2}{*}{ No. } & \multirow{2}{*}{$\begin{array}{c}\text { Pendekatan Saintifik } \\
\text { Langkah }\end{array}$} & \multicolumn{2}{|l|}{ Literasi Saintifik } \\
\hline & & Kompetensi & Indikator \\
\hline 1 & \multirow{2}{*}{ Mengamati } & Menjelaskan masalah secara ilmiah & A1 \\
\hline 2 & & Melakukan penyelidikan ilmiah & B3 \\
\hline 3 & \multirow{3}{*}{ Menanya } & Merencanakan penyelidikan ilmiah & B1 \\
\hline 4 & & Menjelaskan masalah secara ilmiah & A2 \\
\hline 5 & & Merencanakan penyelidikan ilmiah & B2 \\
\hline 6 & \multirow{3}{*}{ Mengolah informasi } & Melakukan penyelidikan ilmiah & B4 \\
\hline 7 & & Menafsirkan data secara ilmiah & A3 \\
\hline 8 & & Menafsirkan data secara ilmiah & A4 \\
\hline 9 & \multirow{2}{*}{ Mengomunikasikan hasil } & Mengomunikasikan informasi ilmiah & A5 \\
\hline 10 & & Mengomunikasikan informasi ilmiah & A6 \\
\hline 11 & \multirow{2}{*}{ Menelaah kembali } & Mengevaluasi penyelidikan ilmiah & B5 \\
\hline 12 & & Mengevaluasi penyelidikan ilmiah & B6 \\
\hline
\end{tabular}

Tabel 3. Sebaran topik setiap LKS

\begin{tabular}{ccc}
\hline LKS & Topik & Pelajaran Terkait \\
\hline A & Teks Eksplanasi COVID-19 & Bahasa Indonesia \& IPA \\
\hline B & Upaya pencegahan COVID-19 & PPKn \& IPS \\
\hline C & Pembuatan Masker & IPA \& SBdP \\
\hline D & Gambar Peta Gejala COVID-19 di Tubuh Manusia & Bahasa Indonesia \& SBdP \\
\hline E & Kebijakan pencegahan COVID-19 & PPKn \& IPS \\
\hline F & Pembuatan Hand Sanitizer & IPA \& SBdP \\
\hline G & Pesan Para Dokter terkait Covid-19 & Bahasa Indonesia \& IPS \\
\hline H & Cara masyarakat menanggapi COVID-19 & PPKn \& IPS \\
\hline I & Pembuatan Disinfektan & IPA \& SBdP \\
\hline J & Tanggapan Grace Natalie terhadap COVID-19 & Bahasa Indonesia \& PPKn \\
\hline K & Keadaan Masyarakat Sekitar Ketika Pandemi COVID-19 & PPKn \& IPS \\
\hline L & Pembuatan Ember Berkran untuk Cuci Tangan & IPA \& SBdP \\
\hline
\end{tabular}

Keabsahan LKS ditentukan berdasarkan validasi pakar. Validasi dilakukan terhadap keselarasan butir LKS dengan matriks indikator literasi saintifik dan tahap inti pendekatan saintifik, kesesuaian butir LKS dengan langkah pembelajaran, ketepatan panduan penilaian dengan pertanyaan, serta kecocokan dengan jenjang sekolah. Pakar yang dipilih yaitu akademisi yang 
memiliki kepakaran literasi saintifik (1 orang) dan kesehatan (1 orang) serta praktisi pembelajaran sekolah dasar (1 orang) dan penyunting naskah bacaan anak (1 orang). Hasil validasi berupa penilaian terhadap setiap butir pertanyaan LKS yang diolah menggunakan persamaan 1 kemudian ditafsirkan berdasarkan tabel 4. Berdasarkan tabel tersebut, butir LKS dapat digunakan kalau memenuhi kriteria 'sangat layak' atau 'cukup layak'.

$$
\begin{aligned}
& P(s)=\frac{s}{N} \times 100 \% \\
& \text { (Persamaan 1) } \\
& \text { keterangan: } \\
& P(s) \quad=\text { persentase setiap butir LKS } \\
& s \quad=\text { skor setiap butir LKS } \\
& N \quad=\text { jumlah keseluruhan butir LKS }
\end{aligned}
$$

Tabel 4. Penafsiran Penilaian

\begin{tabular}{cc}
\hline $\begin{array}{c}\text { Rentang Rerata } \\
\text { Penilaian Pakar }(\%)\end{array}$ & $\begin{array}{c}\text { Kriteria Kelayakan } \\
\text { Instrumen }\end{array}$ \\
\hline $7,001 \leq \% \leq 10,000$ & Sangat layak \\
\hline $4,001 \leq \% \leq 7,000$ & Cukup layak \\
\hline $0,000 \leq \% \leq 4,000$ & Tidak layak \\
\hline
\end{tabular}

Untuk keandalan LKS diukur berdasarkan nilai konsistensi internal yang diolah menggunakan persamaan 2. LKS memenuhi kriteria dapat digunakan kalau nilai $\propto$ sebagai acuan koefisien keandalan lebih besar dari 0,700 (Fraenkel, Wallen, \& Hyun, 2012; Cronbach, 1951).

$$
\begin{aligned}
& \alpha=\frac{n}{n-1}\left(1-\frac{\sum_{i} V_{i}}{V_{t}}\right) \quad \text { (Persamaan 2) } \\
& \text { keterangan: } \\
& \begin{array}{ll}
\alpha \quad=\text { koefisien alfa } \\
n \quad=\text { jumlah butir LKS } \\
V_{i} \quad=\text { simpangan baku butir LKS } \\
V_{t} \quad=\text { simpangan baku keseluruhan }
\end{array}
\end{aligned}
$$

\begin{tabular}{|c|c|c|}
\hline Pelajaran & $:$ & IPA \& SBdP \\
\hline Topik & $:$ & Pembuatan Hand Sanitizer \\
\hline $\begin{array}{c}\text { Literasi } \\
\text { Saintifik }\end{array}$ & : & $\begin{array}{c}\text { Mengevaluasi argumen dan } \\
\text { bukti ilmiah dari beragam tipe } \\
\text { sumber }\end{array}$ \\
\hline Langkah & $:$ & Menelaah kembali \\
\hline Pertanyaan & : & $\begin{array}{c}\text { Apa saja kelebihan dan } \\
\text { kekurangan pembuatan hand } \\
\text { sanitizer dalam video tersebut? }\end{array}$ \\
\hline $\begin{array}{l}\text { Panduan } \\
\text { Penilaian }\end{array}$ & : & $\begin{array}{l}\text { Siswa dapat menyebutkan } \\
\text { kelebihan dan kekurangan dari } \\
\text { sisi: (1) alat dan (2) bahan yang } \\
\text { digunakan serta (3) langkah } \\
\text { pembuatan. }\end{array}$ \\
\hline $\begin{array}{c}\text { Skor } \\
\text { Maksimal }\end{array}$ & & 3 poin / butir pertanyaan \\
\hline
\end{tabular}

LKS tersebut diterapkan dalam pembelajaran jarak jauh kepada 35 siswa sekolah dasar yang mengalami pembelajaran jarak jauh seiring pandemi Coronavirus 2019-20. Karena itu, pengambilan sampel dalam riset ini menggunakan teknik convenience sampling (Fraenkel, Wallen, \& Hyun, 2012).
Tabel 5. Contoh matriks penyusunan butir LKS

Hasil validasi pakar secara rinci dan keseluruhan pelaksanaan dapat dilihat melalui tabel 6. Pelaksanaan yang dilakukan terbatas di satu kelas, yaitu kelas V di salah satu madrasah ibtidaiyyah di Kabupaten Kudus menunjukkan bahwa setiap LKS dapat ditanggapi oleh siswa selama pembelajaran jarak jauh. Rincian data menunjukkan bahwa tanggapan siswa (butir yang diisi) memiliki rerata 91,27 dan median 90,30 serta ketepatan tanggapan (butir yang tepat) memiliki rerata 76,43 dan median 75,69.

Profil literasi saintifik terendah didapat dari LKS H (Cara masyarakat menanggapi COVID-19). Ketika pembelajaran, siswa diminta untuk menyimpulkan apakah Kabupaten Kudus sudah masuk zona merah atau belum berdasarkan informasi saduran berita PDP Virus Corona di Kudus Bertambah Lagi Jadi 22 Orang yang ditayangkan oleh Kompas.com pada 26 Maret 2020 pukul 19.12 WIB (Nugroho, 2020). Namun, ternyata siswa banyak yang belum bisa menyimpulkan secara tepat. Kelemahan pengetahuan istilah terkait tampak turut memengaruhi hasil ini, misalnya pembedaan PDP (Pasien Dalam Pengawasan), ODP (Orang Dalam Pengawasan), dan OTG (Orang Tanpa Gejala). Karena itu, perlu dilakukan langkah awal berupa memastikan siswa sudah mengerti istilah terkait 
topik pembelajaran. Profil rendah juga diperoleh dari LKS A (Teks Eksplanasi COVID-19). Berdasarkan teks eksplanasi yang disajikan, siswa masih kesulitan untuk menyimpulkan bagian tubuh yang secara umum menjadi sasaran serangan COVID-19. Kesalahan yang kami lakukan barangkali untuk LKS A yang dilakukan pertama ialah tidak menyertakan gambar rinci. Ini tampak dari butir LKS D (Gambar Peta Gejala COVID-19 di Tubuh Manusia) yang notabene menunjukkan titik tubuh yang diserang COVID-19 menghasilkan profil jauh lebih baik.

Tabel 6. Hasil validasi pakar dan pelaksanaan LKS

\begin{tabular}{ccccccccc}
\hline \multirow{2}{*}{ LKS } & \multicolumn{7}{c}{ Validasi Pakar } & Pelaksanaan \\
\cline { 2 - 9 } & $\mathbf{1}$ & $\mathbf{2}$ & $\mathbf{3}$ & $\mathbf{4}$ & Rerata & Kelayakan & $\boldsymbol{\alpha}$ & Keandalan \\
\hline A & 7 & 6 & 7 & 7 & 6.75 & Cukup layak & 0,710 & Dapat digunakan \\
\hline B & 8 & 7 & 8 & 8 & 7.75 & Sangat layak & 0,798 & Dapat digunakan \\
\hline C & 8 & 7 & 6 & 7 & 7.00 & Cukup layak & 0,724 & Dapat digunakan \\
\hline D & 7 & 8 & 7 & 8 & 7.50 & Sangat layak & 0,732 & Dapat digunakan \\
\hline E & 8 & 6 & 5 & 7 & 6.50 & Cukup layak & 0,843 & Dapat digunakan \\
\hline F & 7 & 7 & 6 & 8 & 7.00 & Cukup layak & 0,701 & Dapat digunakan \\
\hline G & 8 & 7 & 8 & 7 & 7.50 & Sangat layak & 0,839 & Dapat digunakan \\
\hline H & 7 & 6 & 6 & 7 & 6.50 & Cukup layak & 0,703 & Dapat digunakan \\
\hline I & 8 & 7 & 6 & 8 & 7.25 & Sangat layak & 0,734 & Dapat digunakan \\
\hline J & 7 & 7 & 7 & 7 & 7.00 & Cukup layak & 0,839 & Dapat digunakan \\
\hline K & 7 & 8 & 6 & 7 & 7.00 & Cukup layak & 0,772 & Dapat digunakan \\
\hline L & 8 & 7 & 8 & 8 & 7.75 & Sangat layak & 0,824 & Dapat digunakan \\
\hline
\end{tabular}

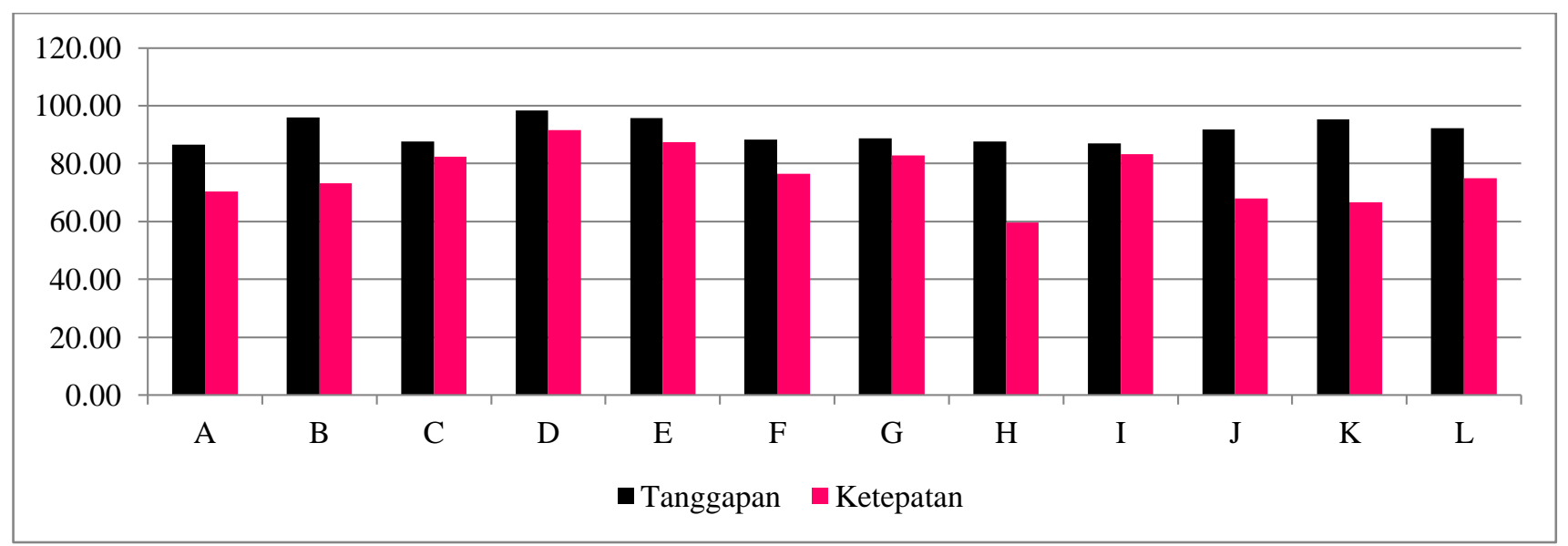

Gambar 1. Perbandingan antara tanggapan dan ketepatan setiap LKS 
Hasil pelaksanaan menyampaikan bahwa LKS perlu mengalami evaluasi sebelum dapat dipakai lebih luas. Pemakaian lebih luas dapat digunakan untuk keperluan praktik pembelajaran maupun replikasi riset. Perbandingan antara tanggapan dan ketepatan setiap LKS yang ditampilkan melalui gambar 2 menunjukkan bahwa literasi saintifik siswa belum dilatih secara optimal, walau setiap butir LKS dapat ditanggapi secara maksimal oleh siswa selama pembelajaran.

Pelaksanaan memang menunjukkan bahwa literasi saintifik siswa belum dilatih secara optimal. Namun, selama memandu pembelajaran jarak jauh, kami turut bertanya tentang makna sekolah pada masa sekarang. Dalam memandu pembelajaran jarak jauh menggunakan LKS yang kami susun, siswa dapat menanggapi secara maksimal setiap alur yang disajikan, mulai dari membaca, mengamati, bertanya, sampai menjawab pertanyaan.

Fakta tersebut menunjukkan bahwa pada masa sekarang, kalau pembelajaran di sekolah atau lembaga pendidikan secara umum dianggap hanya untuk memperoleh pengetahuan saja, tentu kehadirannya tak lagi punya makna. Apalagi dalam bermasyarakat, orang tidak lagi memandang latar lembaga pendidikan sebagai sesuatu yang 'lebih'. Masyarakat sudah memahami bahwa nilai penting seseorang bukan berdasarkan modal yang dimiliki, melainkan karena aksi yang dilakoni (Setiawan, 2020, hal. 142; Setiawan, Puspaningrum, \& Umam, 2019, hal. 191; OECD, 2019, hal. 3). Karena itu, lembaga pendidikan diharapkan bukan sekadar menghasilkan output, tapi sekaligus memberikan outcomes.

Keadaan tersebut membuat lembaga pendidikan yang memiliki format full time seperti sekolah/madrasah berasrama dan pondok pesantren, mungkin masih punya makna eksklusif berupa melatih keterampilan dan membiasakan sikap yang dipandang baik, benar, dan mulia. Terdapat kecenderungan ketika siswa tinggal di sekolah/madrasah berasrama atau pondok pesantren, mereka berupaya untuk beradaptasi, hidup mandiri, dan terbiasa berkomunikasi (Velasufah \& Setiawan, 2020, hal. 2). Lingkungan seperti ini dapat memunculkan serangkaian tindakan untuk mendorong kemunculan perilaku yang diharapkan, menciptakan hubungan interpersonal yang baik dan iklm sosio-emosional yang positif, guna membuat dan merawat kondisi yang memungkinkan proses pembelajaran produktif dan efektif dapat berlangsung
(Fadhilaturrahmi, 2017, hal. 63). Keberlangsungan proses yang dibiasakan dapat menjadi sarana untuk memberikan output dan outcomes yang maksimal (Setiawan, 2017, hal. 26).

\section{SIMPULAN}

Riset ini memberi hasil berupa lembar kegiatan literasi saintifik untuk pembelajaran jarak jauh topik penyakit Coronavirus 2019 (COVID19) bagi siswa sekolah dasar, berdasarkan tahap inti pendekatan saintifik serta indikator literasi saintifik, yang yang telah ditinjau dan dinilai oleh para pakar dan diterapkan dalam pembelajaran.

\section{UCAPAN TERIMA KASIH}

Rasa terima kasih kami sampaikan kepada Syarofis Siayah dari Pondok Tahfifidh Putri Anak anak (PTPA) Yanaabii'ul Qur'an, Kudus, Indonesia; Arij Zulfi Mufassaroh dari Madrasah Yayasan Masjid Raya (YAMRA) Merauke, Papua; Surotul Ilmiyah dari Xiangya School of Public Health, Central South University (CSU), Changsha, Hunan, China; serta Wahyu Eka Saputri dari Universitas Muria Kudus (UMK) Kudus, Indonesia atas bimbingan dan bantuan teknis selama melakukan riset.

\section{DAFTAR PUSTAKA}

Creswell, J. W. (2014). Research Design Qualitative, Quantitative, and Mixed Methods Approaches (Edisi Keempat ed.). (V. Knight, Penyunt.) Thousand Oaks: SAGE Publications.

Cronbach, L. J. (1951, Februari 28). Coefficient Alpha and the Internal Structure of Tests. Psychometrika, 16, 297-334.

Fadhilaturrahmi. (2017). Lingkungan Belajar Efektif Bagi Siswa Sekolah Dasar. Jurnal Basicedu: Journal of Elementary Education, 1(2), 7684.

Fraenkel, J. R., Wallen, N. E., \& Hyun, H. H. (2012). How to Design and Evaluate Research in Education (Edisi Kedelapan ed.). (S. Kiefer, Penyunt.) New York City: McGraw-Hill Companies.

Gold, L., \& Maitland, C. (1999). What's the difference? A review of contemporary research on the effectiveness of distance learning in higher education. Washington: Institute for Higher Education Policy.

Holmberg, B. (2005). The Evolution, Principles and Practices of Distance Education. Oldenburg 
: Bibliotheks-und Informationssystem der. Carl von Ossietzky Universität Oldenburg.

Hui, D. S., E., I. A., Madani, T. A., Ntoumi, F., Kock, R., Dar, O., et al. (2020, Februari). The continuing 2019-nCoV epidemic threat of novel coronaviruses to global healthThe latest 2019 novel coronavirus outbreak in Wuhan, China. International Journal of Infectious Diseases, 91, 264-66.

Ilmiyah, S. (2020, Februari 11). Surotul Ilmiyah PBNU Menjawab Tantangan Virus Corona. Dipetik April 18, 2020, dari YouTube alobatnic: https://youtu.be/SPdc4WT8BCg

Ilmiyah, S. (2020, Maret 22). Surotul Ilmiyah Upaya PBNU Mencegah Penyebaran COVID-19. Dipetik April 13, 2020, dari YouTube alobatnic: https://youtu.be/rYlypLWR3Qw

Irene, Saleh, R. R., Foresto, B., Djuanda, R. E., Prayogo, A., Arianti, A., et al. (2020, Maret 18). Pesan Para Dokter terkait Covid-19. Dipetik April 18, 2020, dari YouTube alobatnic: https://youtu.be/F1IiXodT3MQ

Johns Hopkins CSSE. (2020, April 19). Coronavirus COVID-19 Global Cases by the Center for Systems Science and Engineering (CSSE) at Johns Hopkins University (JHU). Dipetik April 19, 2020, dari ArcGIS: https://gisanddata.maps.arcgis.com/apps/ops dashboard/index.html\#/bda7594740fd40299 423467b48e9ecf6

Kemendikbud. (2020, Maret 16). Surat Edaran Nomor 3 Tahun 2020 tentang Pencegahan COVID-19 pada Satuan Pendidikan. Dipetik April 13, 2020, dari LLDIKTI Wilayah I Sumatera Utara: https://lldikti1.ristekdikti.go.id/berkas/semen dikbud032020pencegahancorona.pdf

Louisa, G. N. (2020, Maret 17). Tanggapan Grace Natalie terhadap COVID-19. Dipetik April 18, 2020, dari YouTube alobatnic: https://youtu.be/gwbOH79C9uo

Nugroho, P. D. (2020, Maret 26). PDP Virus Corona di Kudus Bertambah Lagi Jadi 22 Orang. Dipetik Maret 27, 2020, dari Kompas.com: https://regional.kompas.com/read/2020/03/2 6/19125571/pdp-virus-corona-di-kudusbertambah-lagi-jadi-22orang?page $=$ all\#page 3

OECD. (2019). PISA 2018 Assessment and Analytical Framework. Paris: OECD Publishing.

Roshayanti, F. (2019, Agustus 21). Desain Pembelajaran Sekolah Dasar. (A. R. Setiawan, Pewawancara)
Setiawan, A. R. (2017). Penerapan Pendekatan Saintifik untuk Melatihkan Literasi Saintifik dalam Domain Kompetensi pada Topik Gerak Lurus di Sekolah Menengah Pertama. Bandung: Universitas Indonesia.

Setiawan, A. R. (2020, April 6). Di Mana Letak Penting Lembaga Pendidikan? Dipetik April 6, 2020, dari Alobatnic: https://alobatnic.blogspot.com/2020/04/dimana-letak-penting-lembagapendidikan.html

Setiawan, A. R. (2020, Januari 24). Pembelajaran Tematik Berorientasi Literasi Saintifik. Jurnal Basicedu: Journal of Elementary Education, 4(1), 71-80.

Setiawan, A. R. (2020). Pendidikan Literasi Finansial Melalui Pembelajaran Fiqh Mu'āmalāt Berbasis Kitab Kuning. Nazhruna: Jurnal Pendidikan Islam, 3(1), 138-159.

Setiawan, A. R., Puspaningrum, M., \& Umam, K. (2019). Pembelajaran Fiqh Mu'āmalāt Berorientasi Literasi Finansial. Tarbawy: Indonesian Journal of Islamic Education, 6(2), 187-102.

Simonson, M. (2019). Distance Learning Journal (Book 2) (Vol. 16). Charlotte: Information Age Publishing.

Sugiyono. (2018). Metode Penelitian Bisnis: Pendekatan Kuantitatif, Kualitatif, Kombinasi, dan $R \& D$ (Edisi ke-3 ed.). (S. Y. Suryandari, Penyunt.) Bandung: Alfabeta.

UNESCO. (2020, Maret 4). 290 million students out of school due to COVID-19: UNESCO releases first global numbers and mobilizes response. Dipetik April 13, 2020, dari UNESCO: https://en.unesco.org/news/290million-students-out-school-due-covid-19unesco-releases-first-global-numbers-andmobilizes

UNESCO. (2020, April 13). COVID-19 Educational Disruption and Response. Dipetik April 13, 2020, dari UNESCO: https://en.unesco.org/themes/educationemergencies/coronavirus-school-closures

Velasufah, W., \& Setiawan, A. R. (2020, April 13). Nilai Pesantren Sebagai Dasar Pendidikan Karakter. Thesis Commons, 1-8. 